\title{
Coercive police interrogation in India: A sociological perspective
}

\author{
STEVEN H MILES
}

Jinee Lokaneeta, The truth machines: Policing, violence, and scientific interrogations in India. US Edition: Ann Arbor University of Michigan Press, March 2020, Kindle: INR 2795. 262 pp, ISBN-13: 978-0472054398. Indian edition: Hyderabad: Orient Blackswan, 2020, Paperback, INR 795, 264 pgs, ISBN-9789390122028.

This fascinating book examines the widespread practice of coercive interrogation by police in India. This kind of coercion is typically non-judicial in that it is not imposed as a sentence. Rather, it is embedded, deeply ingrained, social and political inertia which, in Dr Lokaneeta's view, is a state with the destructive legacy of colonialism striving to evolve into liberal modern policies. I note that the functions of police coercion in such societies are largely suppression of crime, protection of police corruption, and obtaining confessions for trial. Dr Lokaneeta takes the unusual approach of considering the infrastructure of torture from the perspective of sociology as described by Max Weber, Foucault and others. This differs from the more common approach taken by most torture scholars who work from psychological (eg Philip Zimbardo or Stanley Milgram who focused on torturers' deference to the authority of the regime), human rights (Amnesty International), or cultural (eg Malise Ruthven focusing on how a torturing culture creates evil, subhuman enemies who merit torture not constrained by ordinary morality) perspectives. This sociological perspective puts the police as a site of state power, a useful choice but one that leaves the political constraints and instructions to police relatively less considered.

Police authority and practices are a legacy of colonial rule going as far back as the Indian Penal Code of 1860. In 1971, the Gore Committee (1) was a major stepping stone towards

\footnotetext{
Author: Steven H Miles (miles001@umn.edu), Author and Professor Emeritus of Medicine and Bioethics, University of Minnesota Medical School. Minneapolis 55455, USA.

To cite: Miles SH. Coercive police interrogation in India: A sociological perspective. Indian J Med Ethics. 2020 Jul-Sep; 5(3) NS: 248. DOI: 10.20529/ IJME.2020.076.

Published online on July 17, 2020.

Manuscript Editor: Sanjay A Pai

(c) Indian Journal of Medical Ethics 2020
}

modernising policing in India and decreasing abuses. This book elegantly details the major ensuing reports and important judicial rulings in India. Collectively, this effort fueled calls and efforts for better police training, science-based policing, and curtailing police torture. It also fostered the emergence of generations of truth machines and ultimately interrogation under sedation (narcoanalysis). There is a fascinating account of the history of the role and false science of truth serums, lie detectors and brain scans. Such truth machines are attractive because they look modern, "scientific" and more humane than torture (if one does not count the eventual penal consequences of the false confessions that are elicited).

There is something of a disconnect between the interrogations by truth detectors that is described and the widespread practice of brutal custodial interrogation by police. $\mathrm{Dr}$ Lokaneeta does not comment on the allocation of these "scientific interrogations" except for the tantalising comment that narcoanalysis was primarily being used "for economic offenses" (rather than for persons suspected of crimes of violence) but the case reports do not illustrate this.

I was struck by how the author focused on abuses and efforts to reform abuses while largely ignoring the impunity of the interrogating torturers. Any reform of the pervasive torture by Indian police requires accountability to the new standards. The fact that India's punishment of torturers is rare and not compiled on public databases indicates that despite commissions and reforms, torture remains deeply institutionalised in India. It is not enough to claim that the current institutionalisation of torture is the legacy of colonialism when India is a unique democracy over an entrenched system of castes, including those considered outcastes or dalits.

Overall, this is an essential work on the history of coercion and efforts to regulate it in India. Its discussion of the science behind lie detectors, brain scans and truth serums is also very carefully annotated. The bookshelf on modern torture is small. This book belongs with the best of them.

\section{Reference}

1. Ministry of Home Affairs, Govt of India. The Gore Committee Report on Police Training. New Delhi:MHA; 1971 [cited 2020 Jul 5]. Available from: https://police.py.gov.in/Police\%20Commission\%20reports/THE\%20 GORE\%20COMMITTEE\%20REPORT\%20ON.pdf 